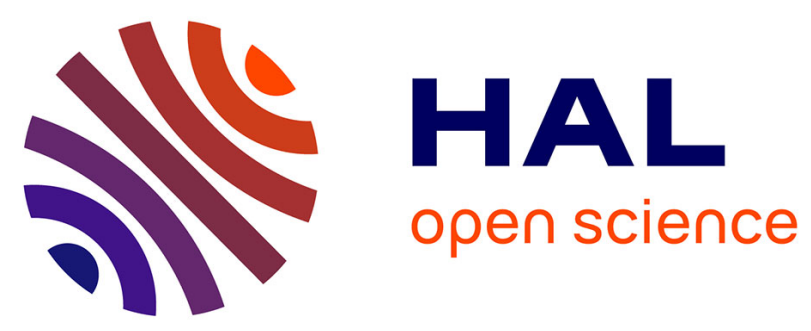

\title{
Combined study of titanium dioxide nanoparticle transport and toxicity on microbial nitrifying communities under single and repeated exposures in soil columns
}

Marie Simonin, Jean M. F. Martins, Gaëlle Uzu, Erwann Vince, Agnès Richaume

\section{To cite this version:}

Marie Simonin, Jean M. F. Martins, Gaëlle Uzu, Erwann Vince, Agnès Richaume. Combined study of titanium dioxide nanoparticle transport and toxicity on microbial nitrifying communities under single and repeated exposures in soil columns. Environmental Science and Technology, 2016, 50 (19), pp.10693-10699. 10.1021/acs.est.6b02415 . hal-01604452

\section{HAL Id: hal-01604452 https://hal.science/hal-01604452}

Submitted on 15 Oct 2021

HAL is a multi-disciplinary open access archive for the deposit and dissemination of scientific research documents, whether they are published or not. The documents may come from teaching and research institutions in France or abroad, or from public or private research centers.
L'archive ouverte pluridisciplinaire HAL, est destinée au dépôt et à la diffusion de documents scientifiques de niveau recherche, publiés ou non, émanant des établissements d'enseignement et de recherche français ou étrangers, des laboratoires publics ou privés. 
1 A combined study of $\mathrm{TiO}_{2}$ nanoparticle transport and toxicity on microbial

2 nitrifying communities under single and repeated exposures in soil columns

3 Marie SIMONIN ${ }^{1,2,3,4^{\dagger}}$, Jean M.F. MARTINS ${ }^{4,5}$, Gaëlle UZU ${ }^{4,6}$, Erwann VINCE ${ }^{4,5}$ and Agnès

4

RICHAUME $1,2,3^{*}$

$5 \quad{ }^{1}$ Université de Lyon, Lyon, France

62 Université Claude Bernard Lyon 1, Villeurbanne, France

$7 \quad{ }^{3}$ CNRS, UMR 5557, Microbial Ecology Lab, Université Lyon 1, Villeurbanne, France

$8 \quad 4$ Université Grenoble Alpes, LTHE UMR 5564, Grenoble F-38000, France

$9{ }^{5}$ CNRS, LTHE, F-38000 Grenoble, France

10

${ }^{6}$ IRD, LTHE, F-38000 Grenoble, France

11

12

*Correspondence to: agnes.richaume@univ-lyon1.fr

13 TPresent address: Department of Biology, Duke University, Durham, NC, USA; Center for the

14 Environmental Implications of Nanotechnology, Duke University, Durham, NC, United States. 
Soils are exposed to nanoparticles (NPs) due to their increasing use in many commercial products. Adverse effects of NPs on soil microorganisms have been reported in several ecotoxicological studies using microcosms. Although repeated exposures are more likely to occur in soils, most of these previous studies were performed as a single exposure to NPs. Contrarily to single contamination, the study of multiple NP contaminations in soils requires the use of specialized setups. Using a soil column experiment, we compared the influence of single and repeated exposures (one, two or three exposures that resulted in the same final concentration) on the transport of titanium dioxide $\mathrm{NPs}\left(\mathrm{TiO}_{2}-\mathrm{NPs}\right)$ through soil and the effect of these different exposure scenarios on the abundance and activity of soil nitrifying microbial communities after a 2-month incubation period. The transport of $\mathrm{TiO}_{2}$-NPs was very limited under both single and repeated exposures and was highest for the lowest concentration injected during the first application. Significant decreases in nitrification activity and ammonia-oxidizing archaea and bacteria populations were observed only for the repeated exposure scenario (three $\mathrm{TiO}_{2}-\mathrm{NP}$ contaminations). These results show that under repeated exposures, the transport of $\mathrm{TiO}_{2}$-NPs to deep soil layers and groundwater is limited and that a chronic $\mathrm{TiO}_{2}-\mathrm{NPs}$ contamination is more harmful for the soil microbiological functioning than a single exposure.

Key-words: $\mathrm{TiO}_{2}$ nanomaterials, chronic and acute exposure, transport, microbial ecotoxicology, nitrification. 


\section{INTRODUCTION}

47 In recent years, several studies have highlighted deleterious effects of metal-oxide nanoparticles (NPs) on soil (micro)organisms and, consequently, on soil functioning and fertility $^{1-3}$. In most of these studies, soils were exposed to single homogeneous applications of NPs into microcosms ${ }^{3}$. However, NPs are more likely to be released onto the soil surface through repeated applications of biosolids, irrigation or through the use of nanofertilizers or nanopesticides ${ }^{4-6}$ and may be leached to further depths through soil porosity ${ }^{7}$. Therefore in contaminated soils NPs are heterogeneously distributed, especially along vertical soil profiles ${ }^{8}$. This heterogeneous distribution of NPs is controlled by the soil physicochemical properties that are known to influence the mobility of colloids according to the colloidal filtration theory $^{9-11}$ and also by NP properties, such as size and/or surface charge ${ }^{7}$.

To date, only a few studies were performed on repeated or chronic NP exposure in soil ${ }^{12}$. The lack of studies dealing with chronic NP toxicity in soils is mainly due to the experimental difficulties associated with executing repeated exposures in microcosm experiments. Implementing more appropriate experimental designs that reflect realistic environmental conditions and consider the distribution of NPs according to soil depth are therefore required.

The aim of this work was to compare the effect of single and repeated NP applications on: (i) the transport of $\mathrm{TiO}_{2}$-NPs through a soil profile, and (ii) their toxicity to the soil microbial communities by focusing on disruption of the nitrification process which is a critical step in the nitrogen cycle. Nitrification is a crucial microbiological process for soil fertility controlled by the activity of both of ammonia- and nitrite-oxidizers that convert ammonium to nitrate. This key step of the nitrogen cycle is known to be very sensitive to environmental stressors, especially chronic disturbances ${ }^{12-14}$. Therefore, the abundance of ammonia-oxidizing archaea 
and bacteria ( $A O A$ and $A O B$, respectively) was selected for monitoring soil toxicity in this study because this endpoint has been proposed as relevant ecological indicators for soil health ${ }^{15,16}$. $\mathrm{TiO}_{2}$-NPs are the most produced NPs and it has been predicted that they may represent $50 \%$ of all engineered NPs retrieved in soil, especially because of the repeated application of biosolids on agricultural soils ${ }^{17,18}$. $\mathrm{TiO}_{2}$-NPs are known to be toxic for microbes, even in the absence of light like in conditions encountered in soils, due to a depolarization and loss of membrane integrity translating in a cell osmotic stress ${ }^{19,20}$

Our experimental design, based on saturated soil columns, enabled the study of the fate and impact of both single and repeated $\mathrm{TiO}_{2}$-NP exposures in soil under more realistic exposure conditions than what can be achieved with classical microcosm experiments. In the context of short-term lab-scale experiment, soil columns were contaminated using three exposure scenarios (one, two, or three applications) resulting in the same total $\mathrm{TiO}_{2}-\mathrm{NP}$ concentrations applied to soil columns (372 mg NPs kg-1 dry soil). After the last NP application, four layers of the contaminated soil columns corresponding to different depths were collected and incubated separately for 2 months to evaluate the impact of $\mathrm{TiO}_{2}-\mathrm{NP}$ exposure on the nitrification process along the soil profile. The nitrification enzyme activity (NEA) and the abundance of $A O A$ and $A O B$ were measured.

\section{MATERIALS AND METHODS}

\section{Soil}

The upper $20 \mathrm{~cm}$ layer of a silty-clay soil (Cambisol, WRB, 2006) under a permanent pasture was collected at Commarin (Côte d'Or, France). After soil sampling, roots and plant litter were 
manually removed. The soil was sieved at $2 \mathrm{~mm}$ and homogenized before storage at $4{ }^{\circ} \mathrm{C}$. The main soil characteristics were analyzed by the Laboratoire d'analyse des sols (INRA Arras, France) following NF ISO protocols: sand, $10 \%$; loam, 51 \%; clay, $39 \%$; pH 7.7; organic matter (OM), 7.9\%; cation exchange capacity (CEC), $20.1 \mathrm{cmol} \mathrm{kg}^{-1}$; water holding capacity (WHC), 51 $\%$; and ionic strength, $1.37 \mathrm{mM}$.

\section{$\mathrm{TiO}_{2}$ nanoparticles}

Uncoated titanium dioxide nanoparticles (mixture of anatase $(80 \%)$ and rutile $(20 \%)$ crystal structure) were purchased from Sigma Aldrich (St Louis, USA) with at least $99.5 \%$ purity. The mean primary particle size of the $\mathrm{TiO}_{2}$-NPs was $28.7( \pm 7.1) \mathrm{nm}$ in powder as measured with a ZEISS Ultra 55 scanning electron microscopy-field emission gun (SEM-FEG) and energy dispersive spectroscopy (EDS) with a SDD detector (BRUKERAXS-30 $\mathrm{mm}^{2}$ ).

The size and zeta potential of the $\mathrm{TiO}_{2}$-NPs were characterized using Dynamic Light Scattering (DLS) in the soil solution used as the background solution in column experiments. The soil solution was prepared following the protocol described by Simonin et al. ${ }^{21}$. Briefly, $10 \mathrm{~g}$ of soil dispersed in $50 \mathrm{~mL}$ of ultrapure water were shaken for $30 \mathrm{~min}$ at $180 \mathrm{rpm}$ and $20{ }^{\circ} \mathrm{C}$ in a refrigerated incubator shaker (New Brunswick - Eppendorf, Hamburg, Germany). The solutions were then centrifuged for $20 \mathrm{~min}$ at $8000 \mathrm{~g}$ and $20^{\circ} \mathrm{C}$ (Centrifuge $5804 \mathrm{R}$, Eppendorf, Hamburg, Germany) to eliminate particles larger than $20 \mathrm{~nm}$ according to Stokes' law. The supernatants were collected and stored at $4{ }^{\circ} \mathrm{C}$. The resulting soil solution had a pH of 7.1, an ionic strength of $1.6 \mathrm{mM}$ and a dissolved organic carbon (DOC) concentration of $8.9 \mathrm{mg} \mathrm{L}^{-1}$. Measurements were performed in triplicate with three suspensions of $\mathrm{TiO}_{2}-\mathrm{NPs}(50,25$ and $16.7 \mathrm{mg} \mathrm{L}^{-1}$ ) after dispersion by ultrasonication (Sonication bath, Bioblock Scientific) for $5 \mathrm{~min}$ 
113 to ensure the suspension homogeneity. For each sample, the mean of three measurements

114 was recorded.

\section{Exposure of soil in columns to single and repeated $\mathrm{TiO}_{2}-\mathrm{NP}$ applications}

Soil exposures to NPs were performed in 1 × $10 \mathrm{~cm}$ glass columns (C10/10, GE Healthcare),

131 homogeneously packed with soil (8 g equivalent dry soil), at $28^{\circ} \mathrm{C}$ in the dark (see Figure S1 132 for schematic figure of the column experimental set up). Flow adaptors (AC 10, GE Healthcare) 133 were adjusted on the top of the columns to ensure constant and similar soil heights during experiments. At the beginning of the experiment, soil columns were saturated and leached

Three $\mathrm{TiO}_{2}$-NP suspensions were prepared in soil solution for each exposure scenario: $50 \mathrm{mg}$ $\mathrm{L}^{-1}$ for the single exposure experiment, $25 \mathrm{mg} \mathrm{L}^{-1}$ for the two-exposures experiment, and 16.7 $\mathrm{mg} \mathrm{L}^{-1}$ for the three-exposures experiment. For the three exposure scenarios, the soil columns received the same net amount of NPs, corresponding to a final concentration of $372 \mathrm{mg} \mathrm{kg}^{-1}$ dry soil, which is high compared to the predicted $\mathrm{TiO}_{2}$ concentration $\left(1.2 \mathrm{mg} \mathrm{kg}^{-1}\right.$ year $\left.{ }^{-1}\right)$ in European soils ${ }^{18}$. The choice of a high input concentration of $\mathrm{TiO}_{2}$-NPs was made to ensure a titanium concentration in the column effluents that was high enough to be distinguished from the background concentration. Indeed, soils naturally contain very high concentrations of $\mathrm{Ti}^{22}$ (in average $4000-5000 \mathrm{mg} \mathrm{kg}^{-1}$ and $4520 \pm 233 \mathrm{mg} \mathrm{Ti} \mathrm{kg}^{-1}$ dry soil in the studied soil). After saturation and leaching with $100 \mathrm{~mL}$ of the soil solution, the column effluents before NPspiking exhibited an average concentration of $0.33 \pm 0.1 \mathrm{mg} \mathrm{Ti} \mathrm{L}^{-1}$. Since we observed that $\mathrm{TiO}_{2}$-NP aggregation and surface charge were significantly different in water and soil solution ${ }^{21}$, the suspensions of $\mathrm{TiO}_{2}-\mathrm{NPs}$ were prepared in soil solution to achieve a more realistic assessment of the fate and impact of NPs in the soil. 
concentration in the effluents. During the entire transport experiment, the solutions were

137 injected in the column using a peristaltic pump at a flow rate of $0.1 \mathrm{~mL} \mathrm{~min}{ }^{-1}$, which 138 corresponds to a Darcy flow of $0.15 \mathrm{~cm} \mathrm{~h}^{-1}$. After this first step of saturation/leaching, 5 pore 139 volumes (PV) (each pore volume was $6.7 \mathrm{~mL}$ ) of the $\mathrm{TiO}_{2}-\mathrm{NPs}$ suspension (either 50,25 or 16.7 $140 \mathrm{mg} \mathrm{L}^{-1}$ ) were injected and then $10 \mathrm{PV}$ of the soil solution free of $\mathrm{TiO}_{2}-\mathrm{NPs}$ were immediately 141 injected in the columns.

The single exposure experiment was performed as a one-time injection of $50 \mathrm{mg} \mathrm{L}^{-1} \mathrm{TiO}_{2}-\mathrm{NPs}$

143 into six saturated soil columns. Six control columns received the same PV of the soil solution 144 free of $\mathrm{TiO}_{2}-\mathrm{NPs}$.

145 Repeated exposure experiments were conducted as two or three applications of $\mathrm{TiO}_{2}-\mathrm{NPs}_{\mathrm{sith}}$ 14625 and $16.7 \mathrm{mg} \mathrm{L}^{-1}$, respectively in 6 columns for each treatment. Six additional control 147 columns were used for each type of exposure as mentioned above. The successive 148 applications of NPs were separated by a 15-day delay during which columns were maintained 149 horizontally at $28^{\circ} \mathrm{C}$ in the dark at constant moisture.

\section{Transport of $\mathrm{TiO}_{2}$-NPs in soil columns}

151 For each exposure treatment, effluents from a randomly chosen column were continuously 152 sampled into $15 \mathrm{~mL}$ centrifuge tubes (1 mL sampled in 10 minutes) using a fraction collector 153 (Gilson, Minipulse 3). Ti concentrations in the spiking suspensions $\left(C_{0}\right)$ and in the effluents (C) 154 were determined using a microwave assisted (Novawave, SCP Science) strong acid extraction 155 method (hydrofluoric acid + nitric acid) and were used to establish dimensionless $\mathrm{TiO}_{2}$ 156 breakthrough curves $\left(\mathrm{C} / \mathrm{C}_{0}\right)$. Ti concentrations were measured by inductively coupled plasma 157 - optical emission spectrophotometry (ICP-OES; Varian 700-ES, Varian Inc. Scientific 158 Instruments, Palo Alto, USA). Control columns leached with NP-free soil solution enabled the 
159

160

161

162

163

164

determination of the background concentration of titanium in the effluents. In order to ensure the quality of the titanium measurements, a certified reference material was measured along with our samples: Sandy Loam 10, RTC-CRM027, lot HC027 certified reference material from Sigma-Aldrich. The concentrations found were within 95-102\% of the certified values for all measured elements.

Consistently with Nickel et al. ${ }^{23}, \mathrm{TiO}_{2}$-NP concentrations retained in the different soil layers after contamination could not be accurately measured due to the naturally high titanium content of the soil (4520 mg Ti kg-1 dry soil) compared to the $\mathrm{TiO}_{2}-\mathrm{NP}$ input concentration (372 $\mathrm{mg} \mathrm{kg}^{-1}$ ). Indeed, the standard error of the soil total Ti content measurements (233 $\mathrm{mg} \mathrm{kg}^{-1}$ dry soil) was too close to the $\mathrm{TiO}_{2}-\mathrm{NP}$ concentration added to the soil to expect reliable values of $\mathrm{TiO}_{2}-\mathrm{NPs}$ concentration in the different soil layers. Thus, our estimation of the final $\mathrm{TiO}_{2}-\mathrm{NP}$ concentration retained in soil is based on the measured Ti concentrations (mass balance) in the column effluents and not a direct measurement of the Ti concentration in soil.

\section{Impact of $\mathrm{TiO}_{2}$-NPs on the nitrification process along the soil profile}

The impact of $\mathrm{TiO}_{2}$-NPs on soil nitrification activity and ammonia-oxidizing microorganisms abundance as a function of soil depth was studied 2 months after the last exposure to NPs. Immediately after the last exposure, soil columns were sliced in four layers according to the distance from the inlet $(0-2 \mathrm{~cm}, 2-4 \mathrm{~cm}, 4-6 \mathrm{~cm}$ and $6-8 \mathrm{~cm})$. Each slice was then placed into $60 \mathrm{~mL}$ glass flasks and incubated at constant moisture for 2 months at $28^{\circ} \mathrm{C}$ in the dark. This experimental design resulted in 144 samples: 6 column treatments (three exposure scenarios and three control treatments) $\times 4$ depths $\times 6$ replicates. At the end of the incubation time, 1.5 g of soil (equivalent dry weight, $d w$ ) were immediately used for the measurements of 
182

183

184

185

186

187

188

189

190

191

192 Ammonia monooxygenase (amoA) gene abundance measurements for $A O A$ and $A O B$

193 quantification were performed in a final reaction volume of $20 \mu \mathrm{L}$ and contained (final

194 concentrations) $0.5 \mu \mathrm{M}$ of each primer for the bacterial amoA or $0.75 \mu \mathrm{M}$ of CrenamoA616r

195 and $1 \mu \mathrm{M}$ of CrenamoA23f for the archaeal amoA, $2 \%$ bovine serum albumin (BSA), $1 \mathrm{X}$ of

196 QuantiTect SybrGreen PCR Master Mix (Qiagen, Courtaboeuf, France) and $10 \mathrm{ng}$ of soil DNA

197 extract or $10^{7}-10^{2}$ gene copies number of an in-house plasmid containing cloned bacterial

198 (Nitrosomonas europaea, GenBank accession number:L08050) and archaeal (54d9 fosmide

199 fragment ${ }^{24}$ ) $a m o A$ genes. Melting curve analysis confirmed the specificity of amplification of

200 the two genes. 
204

NEA was determined according to the protocol described by Dassonville et al. ${ }^{25}$. Sub-samples

of fresh soil (1.5 g equivalent dry weight) were incubated with $3 \mathrm{~mL}$ of a solution of $\left(\mathrm{NH}_{4}\right)_{2} \mathrm{SO}_{4}$

206

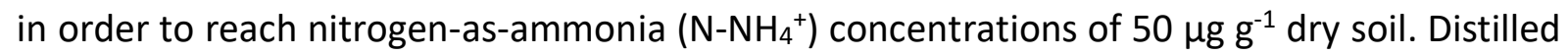
water was added to each sample to achieve $12 \mathrm{~mL}$ of total liquid volume in glass plasma flasks. The flasks were sealed with Parafilm ${ }^{\circledR}$ and incubated at $28{ }^{\circ} \mathrm{C}$ under $180 \mathrm{rpm}$ constant 209 as-nitrate $\left(\mathrm{N}-\mathrm{NO}_{3}{ }^{-}\right) \mathrm{h}^{-1} \mathrm{~g}^{-1}$ dry soil.

\section{Statistical analysis}

All results are presented as means ( \pm standard error). A two-way analysis of variance (ANOVA) and post-hoc Tukey's honest significant difference (HSD) were performed to test the effect of

$218 \mathrm{TiO}_{2}$-NP exposures and soil depth on the nitrifying activity and ammonia-oxidizer abundance 219 for each type of exposure scenario separately. Data were log-transformed prior to analysis 220 when necessary to ensure conformity with the assumptions of normality and homogeneity of 221 variances. T-tests were conducted to compare the aggregation and zeta potential of $\mathrm{TiO}_{2}-\mathrm{NPs}$ 222 in the different spiking suspensions. All statistical analyses were carried out using the $\mathrm{R}$ 223 statistical software $2.13 .2^{26}$. 
226 Characteristics of $\mathrm{TiO}_{2}-\mathrm{NPs}$ in the spiking soil solutions

$227 \mathrm{TiO}_{2}$-NPs were characterized in the suspensions used to contaminate soil columns under the 228 three exposure scenarios. The aggregation of $\mathrm{TiO}_{2}-\mathrm{NPs}$ increased with the concentration 229 (Table 2). At the lowest concentrations applied three times successively in soil columns (16.7 $\left.230 \mathrm{mg} \mathrm{L}{ }^{-1}\right)$, the average $\mathrm{TiO}_{2}-\mathrm{NP}$ hydrodynamic diameter was $111.2( \pm 10.1) \mathrm{nm}$, while at the 231 highest concentration used for the single application $\left(50 \mathrm{mg} \mathrm{L}^{-1}\right)$, the hydrodynamic diameter 232 was $153.9( \pm 9.97) \mathrm{nm}$.

233 The surface charge of $\mathrm{TiO}_{2}$-NPs assessed through zeta potential measurements 234 (electrophoretic mobility) were extremely close for the three suspension concentrations 235 (-15.4 to $-16.6 \mathrm{mV}$; Table 2 ), even if it was significantly lower in the $25 \mathrm{mg} \mathrm{L}^{-1}$ suspension (Table $2362)$.

237 Effect of $\mathrm{TiO}_{2}$-NP concentration and of the number of applications on their mobility in soil

238 The experimental design enabled the study of the influence of $\mathrm{TiO}_{2}-\mathrm{NPs}$ concentration on their 239 transport through soil after single exposures at 16.7, 25 or $50 \mathrm{mg} \mathrm{L}^{-1}$ and after repeated 240 exposures consisting of two or three applications of NPs in suspensions containing 25 and 16.7 $241 \mathrm{mg} \mathrm{L}^{-1}$, respectively (Table 3).

242 The mobility of $\mathrm{TiO}_{2}-\mathrm{NPs}$ decreased with increasing $\mathrm{TiO}_{2}-\mathrm{NP}$ concentration (Table 3). For an 243 injected concentration of $16.7 \mathrm{mg} \mathrm{L}^{-1}, 10.66 \%$ of $\mathrm{TiO}_{2}-\mathrm{NPs}$ were recovered in the effluents, 244 whereas only 4.95 and $2.19 \%$ were recovered when applying the suspensions containing 25 245 and $50 \mathrm{mg} \mathrm{L}^{-1}$, respectively. 
In the columns that received two applications of NPs, the mobility of $\mathrm{TiO}_{2}$-NPs was greatly

247 reduced compared to the mobility measured during the first application (Table 3). Only $0.9 \%$

248 of the added $\mathrm{TiO}_{2}$-NPs were recovered in the effluents for both 25 and $16.7 \mathrm{mg} \mathrm{L}^{-1}$ exposure

249

250 was almost negligible (0.2\%; Table 3).

251

We calculated the final $\mathrm{TiO}_{2}-\mathrm{NP}$ concentration retained in the column on the basis of the mass

252

recovery calculations in the effluents after background subtraction (Table 3). Although the

253

same theoretical $\mathrm{TiO}_{2}-\mathrm{NPs}$ concentration of $372 \mathrm{mg} \mathrm{kg}^{-1}$ was applied to the soil, the final NPs

254 retained concentration differed in the three exposure scenarios (Table 3). The highest final 255

\section{ammonia-oxidizer abundance}

After two months of incubation following the last application of NPs to soil columns, NEA, AOA and $A O B$ abundances were measured. When considering the whole soil column (i.e. the four

265 soil layers), the single exposure (i.e. single application at $50 \mathrm{mg} \mathrm{L}^{-1}$ ) resulted in a significant 266 increase of the AOA abundance (Figure 1; Table 4) but no effect was observed on AOB 267 abundance or NEA (Figure 1; Table 4). After two successive NP applications at $25 \mathrm{mg} \mathrm{L}^{-1}$, 268 neither the NEA nor the ammonia-oxidizer abundances were affected by $\mathrm{TiO}_{2}-\mathrm{NPs}$ 
contamination (Figure 1, Table 4). In contrast, NEA, $A O A$ and $A O B$ abundance were

270 significantly decreased after three repeated applications of $\mathrm{TiO}_{2}-\mathrm{NPs}$ at $16.7 \mathrm{mg} \mathrm{L}^{-1}$ (Figure 1;

271 Table 4).

272 A significant effect of soil depth on NEA was only observed after two and three exposures ( $P$

$273=0.02$ and $P=0.003$, respectively; Table 4). After two soil exposures to NPs, the NEA differed

274 significantly according to soil depth, especially at $2-4 \mathrm{~cm}$ (Figure 2). After three exposures,

275 NEA was significantly more reduced by $\mathrm{TiO}_{2}-\mathrm{NPs}$ in the first $2 \mathrm{~cm}$ than in the other soil layers

276 (Figure 2). No significant statistical interaction between $\mathrm{TiO}_{2}-\mathrm{NPs}$ contamination and soil 277 depth was found (Table 4).

DISCUSSION

\section{Consequences of single and repeated exposures on $\mathrm{TiO}_{2}$-NPs transport in soil}

281 Our experimental design based on soil columns dynamic contamination enabled coupled 282 mobility and toxicity studies of $\mathrm{TiO}_{2}-\mathrm{NPs}$ under single and repeated exposures at different 283 input concentrations. The results showed that the transport of $\mathrm{TiO}_{2}$-NPs is low $(90$ to $99 \%$ of 284 retention) and influenced by the concentration injected in the soil columns. After a single 285 application, $\mathrm{TiO}_{2}-\mathrm{NP}$ retention in soil increased with increasing injected concentrations. 286 Similar behavior of silica nanoparticles has been reported in sand columns by Vitorge et al. ${ }^{27}$, 287 who showed that NPs mobility increases at low concentration regimes. These results can be 288 explained by the increase of $\mathrm{TiO}_{2}-\mathrm{NP}$ aggregation with increasing concentration, which can 289 favor the filtration, deposition and straining of these colloids ${ }^{7,28}$. Although the significant 290 difference of $\mathrm{TiO}_{2}$-NP aggregation between the three concentrations tested in soil solution (42 
$291 \mathrm{~nm}$ maximum, $28 \%$ of the highest hydrodynamic diameter measured) supports this 292 hypothesis, the involvement of other factors such as heteroaggregation kinetics cannot be 293 ruled out.

294 Previous studies on the mobility of uncoated $\mathrm{TiO}_{2}$-NPs in soil reported contrasting results. 295 Nickel et al. $(2015)^{23}$ observed no transport using an input concentration of $1 \mathrm{~g} \mathrm{TiO}_{2}-\mathrm{NPs} \mathrm{L}^{-1}$, 296 while significant transport was recorded in different soils exhibiting low clay contents and 297 ionic strengths with several applied concentrations of $\mathrm{TiO}_{2}-\mathrm{NPs}^{9}$. Here, we show that although 298 low, the transport of $\mathrm{TiO}_{2}-\mathrm{NPs}$ can occur after a single exposure despite the fine texture of the 299 studied soil (39 \% clay and 51 \% loam), especially at the lowest concentration regime, which 300 is more likely to be observed in natural soils. In the case of an accidental spill for which high 301 NPs concentrations can be expected, the mobility of $\mathrm{TiO}_{2}$-NPs will be likely very low, in 302 agreement with a classical blocking mechanism typically observed at high colloidal 303 concentrations ${ }^{27,28}$

304 For repeated exposure in soil columns, an extremely low mobility of $\mathrm{TiO}_{2}$-NPs was observed $305(<1 \%)$ and no concentration effect was observed contrarily to what was observed with the 306 single exposures. The distribution of $\mathrm{TiO}_{2}-\mathrm{NPs}$ along the soil profile could not be measured 307 without specific labeling ${ }^{23}$. However, these results observed in only $8 \mathrm{~cm}$ long columns suggest 308 that in soils repeatedly exposed to $\mathrm{TiO}_{2}-\mathrm{NPs}$, these contaminants would accumulate in the top 309 soil, where, coincidentally, most of the biological activity occurs. In these conditions, it is likely 310 that NPs transport to deeper soil layers and groundwater is limited. In order to confirm this 311 assumption future studies are needed to assess $\mathrm{TiO}_{2}-\mathrm{NPs}$ transport in longer soil columns and 312 in undisturbed soil cores. 
315 Two months after the last application of $\mathrm{TiO}_{2}$-NPs to the soil columns, significant decreases in 316 NEA and ammonia-oxidizer abundances were observed only in soil samples exposed three 317 times to the lowest $\mathrm{TiO}_{2}-\mathrm{NPs}$ concentration $\left(16.7 \mathrm{mg} \mathrm{\textrm {L } ^ { - 1 }}\right)$. In this case, the final $\mathrm{TiO}_{2}-\mathrm{NPs}$ 318 concentration in soil was slightly lower than in the two other exposure scenarios. Surprisingly, 319 we have observed an increase of AOA abundance in the single exposure scenario but without 320 significant changes on NEA. A possible explanation is that a shift occurred in the AOA 321 community and that AOA populations with lower nitrifying activity were stimulated in these conditions. We show in this short-term experiment that soil repeated exposure to $\mathrm{TiO}_{2}-\mathrm{NPs}$

323 has a more deleterious impact on soil microbial community and soil functioning than a single 324 exposure. This result highlights that the nitrifying population did not become more resistant 325 and resilient to $\mathrm{TiO}_{2}$-NPs after multiple exposures. On the contrary, the nitrification process 326 and ammonia-oxidizers became more sensitive, probably because organisms stressed by the 327 previous exposures to NPs had less energy to cope with additional disturbances and/or 328 because of a decrease or a shift of soil microbial diversity ${ }^{29}$. It is well known that a microbial community can become tolerant to various stressors over time through the selection of more tolerant populations and/or the dispersal of specific resistances via mobile genetic elements ${ }^{14,29,30}$. Chronic exposures to pollutants occurring over a longer term will likely have less consequences on nitrification because of potential microbial community adaptation over 333 time, as it was observed by Mertens et al. ${ }^{31}$ after 2 years of exposure to zinc pollution. To gain 334 a better knowledge of NP impact on soil functioning under chronic contamination, it would be 335 necessary to study the effects on microbial activity, abundance and diversity after each 336 exposure and before each new exposure, in order to monitor the resistance and resilience of 337 the microbial community in the long term. This approach could lead to new insights into 
sensitive and tolerant microbial species among nitrifiers and thus on $\mathrm{TiO}_{2}-\mathrm{NP}$ toxicity and

339 adaptation mechanisms in soil.

340 After three NP applications, it is likely that most of $\mathrm{TiO}_{2}-\mathrm{NPs}$ were retained close to the inlet

341 of the column through filtration and/or straining. Although a $\mathrm{TiO}_{2}$ concentration gradient can

342 be expected along the soil profile according to the filtration theory ${ }^{32}$, no significant effect of

343 depth on ammonia-oxidizer abundance was observed. Nitrification was significantly more

344 diminished in the $0-2 \mathrm{~cm}$ and $6-8 \mathrm{~cm}$ layers than in the middle $2-4$ and $4-6 \mathrm{~cm}$ soil layers.

345 With common soluble pollutants, the general assumption is that the highest concentrations

346 induce the most deleterious effects. In the case of NPs, concentration effects are more

347 complex because of aggregation processes and thus the reactivity, bioavailability and toxicity

348 of these contaminants can vary in function of the spiked concentration ${ }^{21,33-35}$. Such changes

349 in NPs aggregation with concentration are likely to induce nonlinear dose-effect

350 relationships ${ }^{36}$. Our results suggest that microbial communities may be affected by $\mathrm{TiO}_{2}-\mathrm{NPs}$

351 at the depths of preferential NP accumulation (top of the soil column) but also at deeper

352 depths likely reached by NPs at lower concentration (bottom of the soil column).

353 The multidisciplinary approach developed in this study enabled the comparison of the impact

354 of single and repeated $\mathrm{TiO}_{2}$-NPs exposures in water-saturated soil columns. The transport of

$355 \mathrm{TiO}_{2}$-NPs in the studied silty-clay soil was evidenced but was limited (over $90 \%$ retention) for

356 both single and repeated applications in $8 \mathrm{~cm}$ long columns. $\mathrm{TiO}_{2}-\mathrm{NPs}_{\mathrm{s}}$ mobility was also shown

357 to increase at low NPs concentrations indicating an aggregation-controlled process.

358 Considering these results, the transport of $\mathrm{TiO}_{2}-\mathrm{NPs}$ to deeper soil layers or groundwater

359 appears limited. Although the repeat exposures resulted in lower final $\mathrm{TiO}_{2}-\mathrm{NP}$ concentrations

360 in soil, the impact was greater on the soil microbial community and on soil functioning (NEA) 
361

378 Table $3 \mathrm{TiO}_{2}$ relative mass recoveries in column effluents for the three applied NPs

compared to the single exposure condition. Future studies should address the fate and effects of $\mathrm{TiO}_{2}$-NPs chronically added to soils in biosolid amendments, as it is one of the most relevant routes by which NPs enter the soil environment ${ }^{37}$. Chronic exposure in short and long term experiments representing realistic scenarios of soil exposure to NPs are urgently needed to study the resistance and resilience of soil microbial communities to these emerging contaminants and their consequences on soil fertility.

\section{TABLE CAPTIONS}

Table 1 PCR primers and thermal cycling conditions used for quantification of ammoniaoxidizer abundances

Table 2 Size and zeta potential of $\mathrm{TiO}_{2}$-NPs in soil solution for the 3 tested concentrations measured with a Nano ZS (Malvern). Means and standard errors are presented $(n=3)$. Values labeled with the same letter do not differ at $P<0.05$.

concentrations in the different exposure scenarios (one, two, or three applications). The final $\mathrm{TiO}_{2}-\mathrm{NP}$ concentration retained in the column was calculated from the relative mass recovery of $\mathrm{TiO}_{2}$-NPs in the effluents. The presented values have been corrected by the Ti background concentration in the effluents measured before NP application $\left(0.33 \mathrm{mg} \mathrm{Ti} \mathrm{L}^{-1}\right)$. 
Table 4 P-values from an ANOVA analysis of the effects of $\mathrm{TiO}_{2}-\mathrm{NPs}$, soil depth and their interaction on nitrification enzyme activity, $A O A$ and $A O B$ abundances for each exposure scenario. Values in bold are significant at $P<0.05$.

\section{FIGURE CAPTIONS}

Figure 1 Effect of $\mathrm{TiO}_{2}$-NPs on nitrification enzyme activity (NEA), AOA and AOB abundances in whole columns (average of the 4 soil depths). Data are expressed as the percentage of change relative to the control treatment for each exposure. Standard errors are presented (n =6). Significant effects are indicated $\left(* * *, P<0.001 ; * *, P<0.01 ;^{*}, P<0.05\right)$.

Figure 2 Effect of $\mathrm{TiO}_{2}-\mathrm{NPs}$ on nitrification enzyme activity (NEA) measured in the four soil column layers (depths 0-2 cm; 2-4 cm; 4-6 cm; 6-8 cm) after one, two or three soil exposures. Data are expressed as percentage of change from the control treatment for each exposure condition. Standard errors are presented $(n=6)$. For each exposure scenario, bars labeled with the same letter do not differ at $P<0.05$.

\section{ACKNOWLEDGMENTS}

Marie Simonin was supported by a Ph.D grant from Rhône-Alpes Region - ARC Environnement. This work was funded by a grant from the French National Program EC2CO Microbien of CNRS. The authors thank the technical assistance of Sungeun Lee. Nitrification enzyme activity measurements were performed at the AME platform (Microbial Ecology 
405

406

407

408

409

410

411

412

413

414

415

416

417

418

419

420

421

422

423

424

425

426

427

428

429

430

431

432

433

434

435

436

437

438

439

440

441

442

443

444

UMR5557-USC1364, Lyon) and quantitative PCR at the DTAMB platform (IFR 41, University

Lyon 1). LTHE is part of the Labex OSUG@2020 (ANR10 LABX56).

\section{REFERENCES}

(1) Dinesh, R.; Anandaraj, M.; Srinivasan, V.; Hamza, S. Engineered nanoparticles in the soil and their potential implications to microbial activity. Geoderma 2012, 173-174, 19-27.

(2) Pan, B.; Xing, B. Applications and implications of manufactured nanoparticles in soils: a review. Eur. J. Soil Sci. 2012, 63 (4), 437-456.

(3) Simonin, M.; Richaume, A. Impact of engineered nanoparticles on the activity, abundance, and diversity of soil microbial communities: a review. Environ. Sci. Pollut. Res. 2015, 1-14.

(4) Brar, S. K.; Verma, M.; Tyagi, R. D.; Surampalli, R. Y. Engineered nanoparticles in wastewater and wastewater sludge - Evidence and impacts. Waste Manag. 2010, 30 (3), 504-520.

(5) Liu, R.; Lal, R. Potentials of engineered nanoparticles as fertilizers for increasing agronomic productions. Sci. Total Environ. 2015, 514, 131-139.

(6) Servin, A.; Elmer, W.; Mukherjee, A.; Torre-Roche, R. D. la; Hamdi, H.; White, J. C.; Bindraban, P.; Dimkpa, C. A review of the use of engineered nanomaterials to suppress plant disease and enhance crop yield. J. Nanoparticle Res. 2015, 17 (2), 1-21.

(7) Cornelis, G.; Hund-Rinke, K.; Kuhlbusch, T.; Brink, N. van den; Nickel, C. Fate and Bioavailability of Engineered Nanoparticles in Soils: A Review. Crit. Rev. Environ. Sci. Technol. 2014, 44 (24), 2720-2764.

(8) Navarro, D. A.; Banerjee, S.; Watson, D. F.; Aga, D. S. Differences in Soil Mobility and Degradability between Water-Dispersible CdSe and CdSe/ZnS Quantum Dots. Environ. Sci. Technol. 2011, 45 (15), 6343-6349.

(9) Fang, J.; Shan, X.; Wen, B.; Lin, J.; Owens, G. Stability of titania nanoparticles in soil suspensions and transport in saturated homogeneous soil columns. Environmental Pollution 2009, 157, 1101-1109.

(10) Martins, J. M. F.; Majdalani, S.; Vitorge, E.; Desaunay, A.; Navel, A.; Guiné, V.; Daïan, J. F.; Vince, E.; Denis, H.; Gaudet, J. P. Role of macropore flow in the transport of Escherichia coli cells in undisturbed cores of a brown leached soil. Environ. Sci. Process. Impacts 2013, 15 (2), 347-356.

(11) Vitorge, E.; Szenknect, S.; Martins, J. M. F.; Barthès, V.; Auger, A.; Renard, O.; Gaudet, J.-P. Comparison of three labeled silica nanoparticles used as tracers in transport experiments in porous media. Part I: Syntheses and characterizations. Environ. Pollut. 2014, 184, 605-612.

(12) Dalzell, D. J. B.; Alte, S.; Aspichueta, E.; de la Sota, A.; Etxebarria, J.; Gutierrez, M.; Hoffmann, C. C.; Sales, D.; Obst, U.; Christofi, N. A comparison of five rapid direct toxicity assessment methods to determine toxicity of pollutants to activated sludge. Chemosphere 2002, 47 (5), 535-545. 
(13) Broos, K.; Mertens, J.; Smolders, E. Toxicity of heavy metals in soil assessed with various soil microbial and plant growth assays: A comparative study. Environ. Toxicol. Chem. 2005, 24 (3), 634-640.

(14) Bissett, A.; Brown, M. V.; Siciliano, S. D.; Thrall, P. H. Microbial community responses to anthropogenically induced environmental change: towards a systems approach. Ecol. Lett. 2013, 16, 128-139.

(15) Schloter, M.; Dilly, O.; Munch, J. C. Indicators for evaluating soil quality. Agric. Ecosyst. Environ. 2003, 98 (1-3), 255-262.

(16) Wessén, E.; Hallin, S. Abundance of archaeal and bacterial ammonia oxidizers - Possible bioindicator for soil monitoring. Ecol. Indic. 2011, 11 (6), 1696-1698.

(17) Keller, A. A.; McFerran, S.; Lazareva, A.; Suh, S. Global life cycle releases of engineered nanomaterials. J. Nanoparticle Res. 2013, 15 (6), 1-17.

(18) Sun, T. Y.; Gottschalk, F.; Hungerbühler, K.; Nowack, B. Comprehensive probabilistic modelling of environmental emissions of engineered nanomaterials. Environ. Pollut. 2014, 185, 69-76.

(19) Sohm, B.; Immel, F.; Bauda, P.; Pagnout, C. Insight into the primary mode of action of TiO2 nanoparticles on Escherichia coli in the dark. Proteomics 2015, 15 (1), 98-113.

(20) Erdem, A.; Metzler, D.; Cha, D. K.; Huang, C. P. The short-term toxic effects of TiO2 nanoparticles toward bacteria through viability, cellular respiration, and lipid peroxidation. Environ. Sci. Pollut. Res. 2015, 22 (22), 17917-17924.

(21) Simonin, M.; Guyonnet, J. P.; Martins, J. M. F.; Ginot, M.; Richaume, A. Influence of soil properties on the toxicity of $\mathrm{TiO} 2$ nanoparticles on carbon mineralization and bacterial abundance. J. Hazard. Mater. 2015, 283, 529-535.

(22) Aubert, H.; Pinta, M. Trace Elements in Soils; Elsevier, 1980.

(23) Nickel, C.; Gabsch, S.; Hellack, B.; Nogowski, A.; Babick, F.; Stintz, M.; Kuhlbusch, T. A. Mobility of coated and uncoated TiO 2 nanomaterials in soil columns-Applicability of the tests methods of OECD TG 312 and 106 for nanomaterials. J. Environ. Manage. 2015, 157, 230-237.

(24) Treusch, A. H.; Leininger, S.; Kletzin, A.; Schuster, S. C.; Klenk, H.-P.; Schleper, C. Novel genes for nitrite reductase and Amo-related proteins indicate a role of uncultivated mesophilic crenarchaeota in nitrogen cycling. Environ. Microbiol. 2005, 7 (12), 19851995.

(25) Dassonville, N.; Guillaumaud, N.; Piola, F.; Meerts, P.; Poly, F. Niche construction by the invasive Asian knotweeds (species complex Fallopia): impact on activity, abundance and community structure of denitrifiers and nitrifiers. Biol. Invasions 2011, 13 (5), 11151133.

(26) R Core Team. R: A language and environment for statistical computing. R Foundation for Statistical Computing. Vienna, Austria 2015.

(27) Vitorge, E.; Szenknect, S.; Martins, J. M. F.; Gaudet, J.-P. Size- and concentrationdependent deposition of fluorescent silica colloids in saturated sand columns: transport experiments and modeling. Environ. Sci. Process. Impacts 2013, 15 (8), 1590-1600.

(28) Solovitch, N.; Labille, J.; Rose, J.; Chaurand, P.; Borschneck, D.; Wiesner, M. R.; Bottero, J.-Y. Concurrent Aggregation and Deposition of TiO2 Nanoparticles in a Sandy Porous Media. Environ. Sci. Technol. 2010, 44 (13), 4897-4902.

(29) Griffiths, B. S.; Philippot, L. Insights into the resistance and resilience of the soil microbial community. FEMS Microbiol. Rev. 2013, 37 (2), 112-129. 
(30) Allison, S. D.; Martiny, J. B. H. Resistance, resilience, and redundancy in microbial communities. Proc. Natl. Acad. Sci. 2008, 105 (Supplement 1), 11512-11519.

(31) Mertens, J.; Broos, K.; Wakelin, S. A.; Kowalchuk, G. A.; Springael, D.; Smolders, E. Bacteria, not archaea, restore nitrification in a zinc-contaminated soil. ISME J. 2009, 3 (8), 916-923.

(32) Huber, N.; Baumann, T.; Niessner, R. Assessment of Colloid Filtration in Natural Porous Media by Filtration Theory. Environ. Sci. Technol. 2000, 34, 3774-3779.

(33) Choi, O. K.; Hu, Z. Q. Nitrification inhibition by silver nanoparticles. Water Sci. Technol. 2009, 59 (9), 1699.

(34) Simon-Deckers, A.; Loo, S.; Mayne-L'hermite, M.; Herlin-Boime, N.; Menguy, N.; Reynaud, C.; Gouget, B.; Carrière, M. Size-, Composition- and Shape-Dependent Toxicological Impact of Metal Oxide Nanoparticles and Carbon Nanotubes toward Bacteria. Environ. Sci. Technol. 2009, 43 (21), 8423-8429.

(35) Menard, A.; Drobne, D.; Jemec, A. Ecotoxicity of nanosized TiO2. Review of in vivo data. Environ. Pollut. 2011, 159 (3), 677-684.

(36) Bernhardt, E. S.; Colman, B. P.; Hochella, M. F.; Cardinale, B. J.; Nisbet, R. M.; Richardson, C. J.; Yin, L. An ecological perspective on nanomaterial impacts in the environment. J. Environ. Qual. 2010, 39 (6), 1954-1965.

(37) Pradas del Real, A. E.; Castillo-Michel, H.; Kaegi, R.; Sinnet, B.; Magnin, V.; Findling, N.; Villanova, J.; Carrière, M.; Santaella, C.; Fernández-Martínez, A.; et al. Fate of Ag-NPs in Sewage Sludge after Application on Agricultural Soils. Environ. Sci. Technol. 2016, 50 (4), 1759-1768. 